\title{
Freedom from the Stranglehold of Time: Shelley's Visionary Conception in Queen Mab
}

\author{
Alan Weinberg \\ University of South Africa
}

\begin{abstract}
:
Notwithstanding ground-breaking studies of Queen Mab, the visionary scope of the work remains largely neglected. The present essay sets out to explore the vision and to show how the concern with Time is integral to it, and not justa framing device for Mab's overview of past, present and future that forms the greater substance of the whole work. The poem envisions the possibility of overcoming time's dominion or at least of coming to terms with it. The reach of the poem encompasses and extends beyond history, the repository of memory and recorded time, thus placing the attack on society within a visionary conceptualization that has no clear boundaries at all, and necessarily so. Shelley's intent is to open up discourse, to saturate his work with thinking that, from the broadest possible imaginary perspective and given his own personal stamp, disrupts time-bound presuppositions that confine human lives within the narrow limits that imprison them.
\end{abstract}

\section{Keywords:}

Percy Bysshe Shelley, Queen Mab, time, vision, necessity, freedom

Yet posterity alone will do ample justice to its merits.

(Publisher's comment, Queen Mab: with Notes, 1831). ${ }^{1}$

Among the most subversive poems in English and, in its early reception, an inspiration to the Chartists and radical left, Queen Mab has been somewhat excluded from the mainstream and it is only in recent times that one has begun to see more scholarly interest in this ardently youthful work. Such interest can in part be attributed to several modern editions of Queen Mab (in some instances abridged) that in order of chronology give it pride of place as the first largescalecomposition of Shelley's career. A number of essays, albeit sporadic, have given the work greater credibility and this is a welcome trend, though there is a sense that the poem's apparent immaturity precludes more sustained attention. ${ }^{2}$ After all, Shelley was in his twentieth year when he composed Queen Mab, and he himself later regarded it as crude and perhaps reckless. ${ }^{3}$ Youthfulness could, on the other hand, be seen as an attraction since Shelley also considered Queen Mab to be a 'sincere overflowing of the heart \& mind, and that at a period when they are most uncorrupted and pure' (Letters, i. 566). When examined on its own terms as indeed it should be - the work emerges as an audacious attempt on Shelley's part to challenge existing

To cite this article: Weinberg, Alan 2016. Freedom from the Stranglehold of Time: Shelley's Visionary Conception in Queen Mab. Romanticism 22.1: 90-106 
paradigmsand,likeitsclassical predecessor, Lucretius's De Rerum Natura, to propose instead an overarching conception of the true nature of things - one that, in its realization as poetry, is of intrinsic value and the prelude to later lyrical epics, most notably Laon and Cythna, Prometheus Unbound and 'The Triumph of Life'. Shelley's radical opposition to an entrenched and venal establishment is built, in Queen Mab, into a wider cosmic framework, and is the foundation of a philosophy of liberation that underlies much of his later work. ${ }^{4}$ The work is 'visionary' in that it imaginatively conceives or constructs its grand subject, using fictive modes of representation (fairy tale, romance, epic, legend etc.), and does not merely expound it in the manner of a French philosophe. Its extraterrestrial reach radically displaces ordinary conventions and consciousness, obliging its reader to inhabit a mental landscape whose perspective is strikingly unfamiliar.

Considered from the point of view of the poet's own development, it seems very natural that Shelley should have written an ambitious visionary poem such as Queen Mab. The work reflects the aspirant poet's idealistic desire to reform the world, his extraordinarily diverse interests and talents (ranging across the liberal arts including the sciences), and moreover, his readiness to think 'large' regarding the pressing issues of his time. Articulating the poet's vision, the nine cantos of verse are accompanied by seventeen prose notes whose frequently extensive commentary becomes an end in itself, disrupting the verse in mid flight, ${ }^{5}$ and precluding the reading of both together in a continuous stream. Admiring Shelley's penchant for mental exploration, Tim Morton argues that the notes can be read as a series of expansive reflections that operate independently of the verse, as if constituting a work within a work, with its own inner logic and interconnections, and carrying the reader to another field of revolutionary and constructivist thought. ${ }^{6}$ Whilst being dynamically released from subordination to the verse proper, as mere 'notes', the essays yet provide a substructure of verifiable claims that, as a system in itself, undergirds the poetry, building a mental fabric that allows the imaginary and the rational - the poetic and philosophical temperament-to interanimate each other. One notices a similar dynamic within the cantos and the notes themselves, as fiction and fact, observation and speculation, representation and instruction are intertwined. ${ }^{7}$ The subtitle, 'a Philosophical Poem: with Notes', is a deliberate ploy intended to disarm the reader, since the typology-highlighting a hybrid work that openly declares its message-has an overcarry of dissidence redolent of the rational standpoint of Lucretius and the French philosophes such as Voltaire (both authors signalled in epigraphs), and considered a shocking threat to the status quo. ${ }^{8}$

Notwithstanding ground-breaking studies of Queen Mab, such as the comprehensive readings of Cameron and Duff, and the specialized reading of Morton, ${ }^{9}$ the visionary scope of the work remains largely neglected. The present essay sets out to explore the vision and to show how the concern with Time is integral to it, and not just a framing device for Mab's overview of past, present and future that forms the greater substance of the whole work. It must be emphasized that the poem is not confined to a representation of linear or sequential temporality: it repeatedly shifts focus from one aspect of time to another, and envisions the possibility of overcoming time's dominion or at least of coming to terms with it. The reach of the poem encompasses and extends beyond history, the repository of memory and recorded time, thus placing the attack on society within a visionary conceptualization that has no clear boundaries at all, and necessarily so. Shelley's intent is to open up discourse, to saturate his work with thinking that, from the broadest possible 
imaginary perspective and given his own personal stamp, disrupts time-bound presuppositions that confine human lives within the narrow limits that imprison them.

\section{Celestial Time}

It can be stated as a premise of what is to follow that the visionary conception in Queen Mab is, in the first instance, multifaceted, and in the second, constitutive of the poem's core structure or raison d'être. It provides far more than a vantage point, in other words, a device in the manner of Volney's Ruins, ${ }^{10}$ set up for convenience to condemn endemic vices of human nature and to dream of a better world. The poet's vision is on the one hand transhistorical, positioned cosmically, outside known temporal boundaries, open to eternal processes and to future possibility, with a view to untapping human potential; and on the other it is historical, focused on the past and present, and on the way these have defeated, or rendered futile, human progress. Differently stated, one might say that a central conception of Queen Mab views history as a limiting condition characterized by mental subjection to a narrow sense of Time - what one might call fixations of memory underwritten by ideology and institution - rather than as a succession of interconnected causal events. Time so constructed - the hold that the past has on present and future - has been the conqueror, wearing human beings down into compliance with error. Time as natural process (mutability) manifests itself in the decay of civilizations (another expression of conquest) and it is in human resistance to this eventuality - in the assertion and futility of power - that we see both a further subjection to Time, and the potential for liberation from social constructs that continue to falsify existence. ${ }^{11}$

Presented at the outset (and in conclusion) as a fairy-tale romance ${ }^{12}$ the narrative proceeds

with the soul of Ianthe's ascent in the chariot of the Fairy Queen Mab (she of Shakesperian and of Spenserian provenance), ${ }^{13}$ the body of Ianthe left behind in a death-like sleep, thus establishing the appropriate conditions for a visionary, extra-terrestrial experience (and not simply an account), one which is meant to be instructive. While appearing to privilege the soul-the fit vehicle, it would appear, of vision - the narrative nevertheless will be drawn back to Ianthe's sleeping body that remains, throughout the soul's journey, a silent, unstated presence, under the watchful eye of her lover, Henry (as we discover at the end), and an unshakeable reminder of mortality (that which 'Rots, perishes, and passes', I. 156). The presentation of contrary modalities highlighted in the separation of body and soul-neither of which can be excluded-forms a pattern that will repeat itself throughout the poem. The poem, as vision, works toward synthesis but, in its exploratory inclusivity, cannot ensure that opposites are, or even can be, reconciled. Shelley's ability to hold in balance opposing perspectives on the grand scale will emerge, in later works, as a distinctive feature of his style. ${ }^{14}$

Interwoven into a notably female-centred scenario-offsetting a male appropriation of discourse and designed to give a further radical twist to the poem ${ }^{15}$ - is the cosmic perspective which is drawn from travel-fantasy works like Ruins and Voltaire's Micromegas, ${ }^{16}$ but which is much more meticulously 'scientific'. The poetic rendering of the 'heavens' is faithful to the new astronomy which had captured Shelley's polymathic interest while a schoolboy at Eton and undergraduate at Oxford, under the influence of his admired mentor, Dr James Lind, and Lind's friends, the astronomers William Herscheland Adam Walker. Especially notable, and key to an appreciation of Shelley's expansive vision, are these lines, presented by an all-observing narrator: 
The magic car moved on.

Earth's distant orb appeared

The smallest light that twinkles in the heaven;

Whilst round the chariot's way

Innumerable systems rolled,

And countless spheres diffused

An ever-varying glory. (I. 249-55)

In this description (recalling the exact observation of Lucretius or Erasmus Darwin, ${ }^{17}$ but also giving an impression of magical flow), the implicit measure of time is absorbed in the steady, systematic motion of 'innumerable' galaxies, inhabiting the vastness of outer space. Movement, which is time, is cyclic, as formations roll around the chariot (itself in movement), and the 'countless spheres' themselves are in constant orbit. If time be a discernible factor here, its expansive rhythm is entirely distinct from that of clock time, which marks out the segments of temporality on earth. The extraordinary profusion of cosmic formations is gathered into an impersonal dance within which the tiny distant earth (itself an orb, implying orbiting sphere) appears as merely a faint variable light (the smallest) from the vantage point of the voyaging chariot, evidently near enough to the earth to see it 'twinkle'. The light of this insignificant object would not be its own, but be borrowed (reflected) from the Sun, and according to Newton, would take about eight minutes to traverse the distance.

This mode of looking from the outside inwards, as it were, to the earth, marks a Spinozist positioning of the mind outside or beyond the spatio-temporal limits that have tended to exaggerate the earth's importance in the larger scheme of things, ${ }^{18}$ and it guarantees that the historical survey in cantos II to VII, focused in the main on politics, commerce and religion, will never be circumscribed by that history - will not be accounted for on its own terms but rather in relation to Time sub specie aeternitatis. There is the sense that, from the very outset of the poem, the poet has, at least in imagination, liberated himself from a persistent earth-centredness which has conditioned centuries of European thought and its collective memory, even though it might pretend to be universal, and in spite of the Copernican revolution and the Enlightenment from which Shelley clearly draws inspiration. Queen Mab herself, so much at home in this wondrous setting (somewhat demystified today by modern technology),becomes the poet's imaginative proxy. She bestows the 'envied boon' (123) of true vision upon the brave and virtuous Ianthe, most worthy of 'Those who have struggled, and with resolute will' have

Vanquished earth's pride and meanness, burst the chains,

The icy chains of custom, and have shone

The day-stars of their age... (I. 125, 126-8)

In fairy-tale fashion (in which dreams come true), the reward is exactly consequent on achievement: it is its perfect complement. Already in Canto I the link is firmly established between freedom from custom, from habitual time-bound and imprisoning social practices inscribed into memory (characterized here as earth's 'pride and meanness'), and a scientifically based, visionary perspective 'That waits the good and the sincere' (124) - that is, Ianthe herself, or at least, her disembodied 'immortal' soul, itself freed from 'The chains of earth's immurement' (188) (the image fusing the bondage of custom with that of bodily constraints). The planetary image (day-star=morning star $=$ Venus or Lucifer) situates her as one of the "harbingers of future good' ( $C P P B S$, ii. 527, note to 1.128), in advance of history and the present time, while identifying her with the celestial spheres and cosmic time. This association of 'what may come' with a larger time-scale consistent with the entire universe is again intimated in the utopian cantos VIII and IX. 
Accompanying the broad prospect of starry firmament, as if viewed from a planetary or stellar probe, are further singular descriptions, alike depicting the vastness of space, the multitude of heavenly bodies, and the brilliance of light and colour that emanates from them.

Vast dimensions and quantities in 'immense concave' (232), 'million constellations' (233), 'infinite colour (234), 'incessantmeteors' (236), give the impression of hyperbole, of overstatement typical of fantasy fiction. Despite the fact that there are just eighty-eight observable constellations (star patterns or asterisms), ${ }^{19}$ it has been argued that the number of possible constellations is infinite, since these 'pictures' depend on the viewpoint of the observer. In any case, terms like 'immense', 'infinite' and 'millions' have been and are commonly used in astronomy to approximate the astonishing extent of the universe, in our present understanding, grander even than Shelley could have imagined it. Like a space ship the chariot 'seems' to chart its way through the 'immense concave', the appearance acknowledging the fact that 'midst' in outer space is not an accurate position or measure, while the concave itself (a celestial sphere) must be perceptual rather than actual. ${ }^{20}$

Following a more specific account of the 'countless spheres', the first canto concludes with the narrator's glowing address to the Spirit of Nature, accommodating all of life on a broad scale and (from his perspective) indifferent to historical detail. ${ }^{21}$ If this divinity is what Spinoza called 'God', then its 'fitting temple' - its habitation - is accordingly 'this interminable wilderness / Of worlds' $(268,265)$. So constituted, 'fitting temple' encapsulates the Shelleyan conception of the universe and of the 'religion' of Nature which he was to hold throughout his brief life. ${ }^{22}$ His is not the concept of a clock-work or harmoniously determinate universe, self-contained, and presided over by a mechanist God (the deism of the Enlightenment which, after a brief and very early flirtation, he strongly rejected). The phrase, 'interminable wilderness', registers the idea of immeasurable cosmic matter, formations and extent, engulfing our own small planet, solar system and galaxy in its unfathomable vastness, and generating a proliferation of new worlds exposed to the 'wild', the laws and accidents that might befall them. In this expanse, human life all but disappears, might seem an irrelevance. The play on 'interminable' (a typically Shelleyan negation of finitude) ${ }^{23}$ indicates that the reference is both to time and space. What is visualized is infinite and will continue for all eternity, has no beginning or end, yet these are principles of existing matter, not of afterlife. In his Note 13, which mostly repeats his notorious first pamphlet, The Necessity of Atheism (1811), Shelley (as commentator) logically supports this inference: he argues that, in the absence of proof that the universe was created, 'we may reasonably suppose that it has endured from all eternity' (CPPBS, ii. 265, ll, 50-51). In astonishing claims such as this, the logic of cosmology and that of fairy-tale seem to coincide in imaginative speculation.

The above is neither an amicable nor a hostile view of creation since its reference is not human but cosmic, its design (if one might call it that) not geocentric, ${ }^{24}$ anthropocentric or theocentric, but of the nature of things (even if Shelley's more personal design is to use this perspective to attack Christianity). It stirs admiration - the extraordinary privilege of witnessing the larger universe and of participating in it. At its 'immensity', the narrator himself comments, 'Even soaring fancy staggers' $(I, 266,267)$, now undercutting the furthest reaches of his (or later Mab's) mental flight, and intimating that no single perspective, no matter how imaginative, can ever encompass the full extent of reality - of Time and Space. It is in the context of this verifiable sublimity-and honest acceptance of the limits of vision - that the fantasy of theistic 
religion, so evidently tied up with human history, and a conception of Time that is miniscule in comparison with the history of the universe - if what is eternal can have a history - will later be revealed in Cantos VI and VII. In his Note to ll. 252-3 ('Whilstround the chariot's way / Innumerable systems rolled' (Note 2)), Shelley clearly reflects his larger concern and anticipates the later exposure of the sham of institutionalized religion:

The plurality of worlds, - the indefinite immensity of the universe is a most awful subject of contemplation. He who rightly feels its mystery and grandeur, is in no danger of seduction from the falshoods of religious systems, or of deifying the principle of the universe. (CPPBS, ii. 239-40,1l.3-6)

Following this corrective note of 'mystery and grandeur' - which, in acknowledging the true limits of knowledge ('indefinite immensity') displaces the deceptions of religious

exaltation - the narrator, in concluding the address to the Spirit of Nature (and Canto I), momentarily reverts to an earthly perspective, claiming, in Spinozist fashion, that everything partakes of that Spirit, 'the lightest leaf' and 'the meanest worm' (I. 269, 272). Reflecting as well the holism of Hinduist philosophy, ${ }^{25}$ Queen Mab establishes a macrocosmic conception within which every minute particle and event is part of, as well as embodies, the larger process. Death, which is graveside food for the fattening worm, is inextricably bound up with life, life with death, but the individual instance which must include our own particular lives is caught up in what is described as an 'Imperishable' scene, the Spirititself being 'Imperishable' (276). The cycles of rebirth are interinvolved in an eternal panorama. Amazement at the fact of unending creation offsets the notable absence of religious consolation for the imperfections of human life, such consolation being, one can only assume, a superstition or idle, egoistic fantasy.

\section{EARTH TIME: PAST AND PRESENT}

The inner core of the composition, extending from Canto II, 109 to the end of Canto VII, concerns the state of mankind as it has been and presently is: that is, in recorded history or, one might say, in 'living memory'. This is the substance of the vision that Mab produces for Ianthe from the vantage point of her 'Hall of Spells' (II. 42), prior to her future prophecy in Cantos VIII and IX. By scanning the past and its immersion in the present (past and present being evidently inseparable), she makes known and, as it were, 'unforgets' its repressed and disguised inequalities, sanctioned by binding tradition, and lays bare the general willing subjection to Time. To make any progress, Ianthe must recognize the truth that is unmasked by Mab, just as later she must apprehend what the future holds. It is upon the development of an historical consciousness- one that is steeped in awareness of Time - that Ianthe's education is based. Importantly Mab's vision is anchored in a dramatic situation that has due consequences for the recipient whose agency is posited as a future potential rather than a demonstrable fact. It would appear that learning is to precede action. It is not enough that Ianthe be immured within the prison of a celestial palace (as Mab puts it), passive and safe in her grand overview of human depravation; she needs to make others happy as well - to free them from their myopic captivity. Her becoming an agent would, it is argued, fulfil nature's will-agency being as it were the spring of her wise passivity. Hence the concern with Ianthe's habitat, the earth, which is also the specific domain of Mab's interest. It is intimated that Ianthe's soul will journey back to her body refreshed for her terrestrial mission, which has its place within the larger scheme of things. 
In Canto II, which briefly surveys the past, a number of historic sites are emblematically depicted - Palmyra (in ancient Syria, the locale of Volney's Ruins (1791) and Peacock's Palmyra $(1806)^{26}$ ), the Pyramids 'Beside the eternal Nile' (126), Solomon's temple in Jerusalem ('old Salem's haughty fane' (137)), Athens, Rome and Sparta, and ruins that might be Mayan, Incan, or even more possibly, the Aztec city, Tenochtitlán (Mexico City) (CPPBS, ii. 537). This brief tour of the ancient world (Africa, Asia, Europe and America) illustrates the decline of ancient civilizations, inevitable though in some cases regrettable. From Canto III, the vision sweeps across the custom-bound present in its exposure of historically entrenched hegemonic power. There is a dual perspective: macrocosmic, from a privileged station in outer space, whose presence is implied by its visionary perspective; and microcosmic, in its documentary focus on the planet, earth. This dual character is easily lost sight of as Mab delivers her persistent lashing of the young poet's three bêtes noires: government (monarchy) (III-IV), commerce (V) and religion (VIVII). Masked by Mab (whose glamour as fairy godmother or enchantress itself disguises a fierce social critic), Shelley's artful attack has all the vitriolic antagonism of an adolescent revolutionary, dissatisfied with the world. The language of diatribe is an obsessive feature of Mab's intellectual armoury - a counterthrust to the spiteful verbal denigration of the honest friend of liberty which it parodies ${ }^{27}$ - but is also an instrument in a more extensive prognosis. There are key moments when Mab stands back from the fray, reasserts the broad scope of her instruction on behalf of Ianthe, and thus sustains a double vision, continuing to find significance in the particular (human society) and the general (universal laws of nature), the one never quite excluding the other from consideration, each as it were interwoven with the other. Opposite perspectives are placed in meaningful relation to each other within an overarching vision. A principle of dialogical balance, and of inclusivity is at work.

A notable instance of such judicious re-positioning of the argument occurs in Canto VI, wherein Mab begins her tirade against religious practice. The history inscribed and immemorialized in 'scripture' is, cosmically speaking, just a moment in time but is nevertheless significant in that religion competes with science for the truth, and is therefore ideologically and politically a greater intrusion and menace than the forms which its feeds - namely the established order of state and finance and church, whose dominant exclusionary discourse is radically undermined and denounced in the central cantos. It is, in other words, the source of a serious distortion of truth that has anchored itself in the mind and in human memory. The reader has to be aware of how the poem has shaped itself in accordance with the broader perspective, and that Mab's paean to Necessity in the latter half of Canto VI-sometimes considered an irrelevance ${ }^{28}$-is appropriately timed to displace the absurdities of religion, being its negation in historic terms.

Necessity provides the philosophy based on observable truth, a non-creative force at the heart of nature, endorsed in Note 12 (the way things are and must be), and broadly consistent with a post-Copernican understanding of the universe. Necessity determines, first of all, that religion can only be shortlived, a temporary, indeed in a sense, momentary, superimposition on the known universe, and a very inaccurate model of it. It cannot survive, and will simply die out and be at best a memorial of a deluded and defunct system that lacks the universal knowledge it would readily claim. Truth must outlive it, truth in this sense, like Necessity, being eternal. This may sound tautological but it is, in fact, revolutionary, since the social order relies on religion for its entrenchment and survival - the doctrine of God (an avenger), Hell 
(his punishment for dissidents) and Heaven (his reward for abject obedience) being a specifically pernicious case in point, IV. 203-20). ${ }^{29}$

The transient nature of religion is first noted in the account of its birth, ascendancy and inevitable decline, Mab indicating its continuing descent 'to the darksome grave, / Unhonoured and unpitied, but by those / Whose pride is passing by like thine' (VI. 140-42). ${ }^{30}$ This funereal result marks the fate in history of investments in the supernatural: they prove to be fallible power structures that eventually lose their efficacy, as we see with obsolete religions of antiquity (which atleast had the merit of respecting nature). The dramatically fleeting state of religion is contrasted with 'these infinite orbs of mingling light, / Of which yon earth is one', throughoutwhich is 'wide diffused / A spirit of activity and life, / That knows noterm, cessation, or decay' (146-9). The reiteration of thework's central themefinds hereits main pronouncement, and itis clear that freedom calls for a perspective that is not in any way bound by a narrow sense of time, time that is simply a tiny fraction of eternity, but which nevertheless absorbs all our earthly attention. The fact that religion is itself trapped in an irresistible process of tempestuous change (duly depicted as 'the sweeping storm of time' (220)) and is due for extinction is for Shelley a splendid irony, and it is underlined in the concluding passage of Canto VI, following the address to 'Necessity! thou mother of the world!' (198). Having established that, in contrastto 'theGod of human error' (199), Necessity 'Requirest no prayers or praises' (200), and that all 'are equal in thy sight' (211) - that in short it is a non-human and nondiscriminating 'all-sufficing Power' (197) - Mab presents Necessity in the guise of the traditional omnipotent deity, as convincingly and emphatically 'Unchangeable' (226).

This last term is the keynote of the whole celebratory account, and should therefore not be taken lightly. The very negative and highly subversive representation of the monotheistic deity in Canto VI is intended to accentuate the violence that has been committed in his name, and to convey as a matter of intense relief the washing away of blood spilt in his honour. In place of his 'ruined fanes' (221) and 'broken altars' (222) is a 'shrine' (226) that (recalling the 'temple of nature' earlier) emerges as nothing other than the perceived evolving world itself ('The sensitive extension of the world' (231)) that does 'the will of strong necessity' (234), life being seen here as inextinguishable and yet in the service of a force greater than itself. In the very last lines of the canto, life, in all its great variety of forms, embodies a ceaseless and relentless evolutionary process that entwines itself with Necessity:

And life, in multitudinous shapes,

Still pressing forward where no term can be,

Like hungry and unresting flame

Curls round the eternal columns

of its [the fane's] strength. (235-8)

The passages on Necessity (amplified in the long prose note [12]) encapsulate the philosophy that serves as a foundation for all Shelley's later work. They anticipate Darwin's evolutionary theory (drawing here on his grandfather, Erasmus Darwin's preliminary scientific musings, in verse), are buttressed by Hume's stringent reasoning on Necessity in his Enquiry Concerning Human Understanding, esp. VIII), Holbach's ethical considerations in Système de la Nature I. xii, and Godwin's recasting of Hume's argument in Political Justice IV:v, and are also significantly indebted to Spinoza, especially in the way Mab reproposes Necessity as the 'Spirit of Nature' (197), in a sense, the true 'God', the fountainhead of a 'religion' that is the end of religion as we have understood it, requiring no sacrifice, dogma, worship, or submission. 
From a strict view of poetical economy, Canto VII of Queen Mab, which rejects Christianity along with the various supreme deities of world religions, might seem superfluous. If, as is claimed in Canto VI, religion is fraudulent and ephemeral, a mere passing fiction which deludes humanity, then it follows that Christianity can be no exception. And Necessity has already replaced the God of monotheistic worship in Mab's pantheon, so, it might be argued, there is no further need to pursue this line of attack. On the other hand, Queen Mab repeatedly uses repetition to its polemical advantage. In the Utopian Canto VIII, folly and degeneracy continue to be derided, but all the more persuasively since, by contrast, in Mab's futuristic vision of a wholly renewed earth they will no longer have currency. Shelley's subject threatens strict social taboos (among which are the prohibitions against atheism), and it becomes as necessary for him as it was for Lucretius, in regard to Roman superstition, continually to taunt readers who will cling to convention. ${ }^{31}$ Religion is an embedded social phenomenon and so, of course, is Christianity.

Thus the brave and defiant announcement early in Canto VII that 'There is no God!' (13) (itself immediately repeated by Mab herself, and again keyed as the subject of Note 13) remains a decisive moment in the poem. Shelley's expulsion from Oxford in March 1811, in his eighteenth year, had already taught him the cost of asserting the 'Necessity of Atheism' (and we notice the importance of 'Necessity' in the title). His inclusion of the same pamphlet in his Notes to Queen Mab gives new life to the historic document, recycling it in a context wherein it might be better understood. This served his purpose admirably. The refutation - given by Mab as if it were in itself a divine pronouncement - is not left to stand on its own but is provided with a corresponding 'proof' which turns out to be a subversion of the very claims made of God.

Since every partis linked to the whole-has individually no beginning or end-the part, it is implied, cannot 'point to the hand / That grasps its term' (VII. 18-19). The scriptures presuppose that there is a 'hand of God', a controlling power, authority and first cause who sets aspatio-temporallimit to things from the very beginning, but this is negated by the infinite chain of Necessity and, of course, the celestial view. In similar fashion, the injunction that follows rejects theidea of creation or that of acreatorgod:

\footnotetext{
let every seed that falls

In silent eloquence unfold its store

Of argument: infinity within,

Infinity without, belie creation;

The exterminable spirit it contains

Is nature's only God. (VII. 19-24)
}

The philosophical argument is underpinned by one that speaks for itself, namely, the seed's own 'silent eloquence'. The falling seed-expressive ofideas as well as physical properties-embodies an infinite process in which the inevitability of death and the potential for life, the past and the future, are forever intertwined. The play on language ('eloquence, argument') continues the transgressive displacement of doctrine (word of God) by 'nature' (24), a concept here used conveniently to encompass all of existence.

Shelley's coinage of 'exterminable' (to mean 'illimitable') echoes 'term' above (19), forcing the reader to prise out the new meaning from its Latin roots (the opposite of the standard definition), to imagine what it is to be outside limits (ex-terminable), spatially and temporally, and so to be aligned with the 'spirit' contained within the seed. In a further playful turn, the fairy queen refigures her grand refutation, in a form of deconstruction gladly appropriating the term 'God' by depriving it of its theistic significance, so allowing it to stand (as it was always meant to stand) for a primal concept, such that (as Shelley explains in the 
note to Mab's sweeping declaration) 'The hypothesis of a pervading Spirit coeternal with the universe, remains unshaken' (Note 13,1l.1-3). ${ }^{32}$ Historical accretions have been unmasked to reveal the kernel idea that is not prescribed bysocialconvention.

The concept of God is so stripped of personal reference that there is no danger of any confusion with the Creator God of Judeo-Christianity, who intervenes intentionally in history, and is said to be the ultimate and presiding authority and judge of everything. This God stands separate from his finite creation which he designs for his own satisfaction. At most, Shelley has, like Spinoza, blurred the distinction between atheism and pantheism, and in consequence he can, with confidence, assert an impersonal 'god-like' principle in harmony with the vast, unfathomable universe, which shows up the absurd pretentions of the Christian deity. Most significantly the temporal parameters within which this deity is said to operate (in Canto VII) encompass a mere fraction of time - 'four thousand years' of recorded history, as Shelley points out in Note 15 (1. 10). ${ }^{33}$ Accordingly God (in his own words) begins his Creation after awaking 'From an eternity of idleness'(VII, 106), and the making of earth 'From nothing' (108) seems the whole point of his 'seven days' toil' (107). This satiric unmasking of the Genesis account of the first five days effectively conveys the geocentric obsession with humanity and a lop-sided time-scale in this and all the other books of the bible. The style of witty deconstruction and defamiliarization (taken further in the note which ridicules the Christian story and is clearly indebted to Paine's The Age of Reason and to Holbach, Volney and Diderot) is ingenious and it makes of Canto VII in some ways the most inventive and imaginative of the cantos in the whole work.

In order to show up the fictionality of the Christian scheme of things, Mab calls up, out of the storehouse of cultural memory, the legendary figure of Ahasuerus or the Wandering Jew, ${ }^{34}$ who is but a fiction himself, but who nevertheless personally attests to the injustice of a religion of which he is the prototypical victim. Ahasuerus is condemned to eternal suffering for spurning Christ, in view of the militancy propounded by Christ's teaching (blessing the sword), the dire results of which he has already foreseen and experienced. For him, the God of Christianity is very much a reality, as are his punishments, decreed in this instance from the Cross. Ahasuerus's answer to Ianthe's ingenuous question, whether there is a God, is therefore affirmative, even though Mab has just refuted his existence. The make-believe constituting the Wandering Jew's emergence and narrative is designed to show, historically, how imprisoning systems of belief become, even though they have no substance or truth.

Ahasuerus makes a mockery of biblical narrative, of its persistent theme of justified revenge from the Creation to the Redemption, making it seem like a bizarre or monstrous fairy tale. Given that his wanderings are eternal and bound up with the entire history of Christianity, he is witness to all its misdeeds, and serves to conjoin the creed with events subsequent to the crucifixion, showing how in time we live out the consequences of religious ideology. In his account, delivered proleptically by Moses, murderer and lawgiver, Christ's message is presented as a hypocritical sham.Ex isting as he does within the story-being physically present at the crucifixion - Ahasuerus interprets the Christian account literally, accepting that the God of peace is actually self-avowedly the God of war. But in Note 15, Shelley provides a more subtle reading. He notably accepts the outstanding virtue of Christ, distinguishing it from the horrors that have been perpetrated in his name. ${ }^{35}$ What, in sum, this clarification amounts to, is that by deifying Christ, his followers have obscured his great humanity. 
Ahasuerus therefore lives out the Christian version of itself, in which the Saviour is represented as justifiably punishing Ahasuerus for the worst heresy, and for all eternity.

Ahasuerus is nobly defiantand serene in his misery, in the manner of Prometheus whom he prefigures, ${ }^{36}$ butheis tied forever, indeed interwoven into, the belief system to which he is opposed. He cannot escape history, unlike the Titanin the later play. What Shelley achieves in Canto VII is the presentation of a fake model of eternity that is bound up with forced or willing submission to a tyrannical God or resistance against him. In opposition to this conception is the model of a non-vindictive, timeless universe which adequately registers the excellence of Christ's humane dedication, later fused into that of Prometheus. It is in anticipation of this condition that Mab earlier declaims: 'The man / Of virtuous soul commands not, nor obeys' (III. 174-5). ${ }^{37}$

\section{Future Time}

In the central cantos of Queen Mab, an alternative of Virtue is proposed, a natural disposition that, in its full reliance on human agency, successively rejects the violent imposition of unequal rule, including the tyranny of money - the commodification of life itself, for the benefit of the rich and powerful. ${ }^{38}$ But it is very clear that oppression persists, its spectral shadow cast over all human endeavour. To succeed Virtue cannot merely oppose these forces, which appear stronger than itself. It must be liberated from the yoke of Time, whose past traces are ingrained in the present (the 'icy chains of custom'), and might to many seem forever inescapable. A resolution is, if such there be, in a very real sense, a philosophical one and its proposition - whether in strictly rational or in imaginative terms - was not only Shelley's concern in Queen Mab, but was revisited and refined in the works that followed.

In the last two cantos (VIII and IX), the all-embracing perspective of timelessness - so powerfully represented in the first cantos - is brought into an approximate conformity with a vision of the future - one that is not predicated on the past, but free of it. Mab releases the future from the 'memory of Time' (VIII. 46), ${ }^{39}$ erasing the persistent hegemony that devastates the earth and obscures awareness of its interconnectedness with the whole cosmic system, of which it is an infinitesimal but integral part. The result is a vision that is idealized, drawn at will from the imaginative armoury of the prophetic Mab (where the 'wonders of the human world' [VIII. 49] are safely kept ${ }^{40}$ and counterbalancing what after all is a pictorial and expository synopsis of the past and present that the fairy queen offers Ianthe, encompassing in its emphasis on humanity just a brief span of time.

Time serves as the frame of reference for the utopian vision, as well as its agent. At the outset of Canto VIII, Mab puts behind Ianthe the present and past, 'a desolate sight' (2) and, placing before her the secrets of the future, follows with an apocalyptic invocation to Time:

Unfold the brooding pinion of thy gloom,

Render thou up thy half-devoured babes,

And from the cradles of eternity...

Tear thou that gloomy shroud.

(VIII. 4-6, 9)

Modelled subversively on Cronus, who 'devoured his own sons as soon as they were born', 41 Time is refigured maternally as a bird releasing her engorged 'babes'. The image underlines the creative transformation out of 'gloom' (one notes the pun on 'brooding') and it is evident that what is invoked is the future potential that has been consumed (or half consumed) by the dismal past. Time is cast here as a dual phenomenon, both blocking progress and potentially enabling it, a figure of suspension (death) and release (rebirth). Its power to "Tear ... that gloomy shroud' that evidently envelops it, obscuring 'Hope', is capable of being drawn from 'the cradles of eternity', the timeless source of every new 
beginning, and the principle that, as we have seen, underlies Mab's wondrous vision of the vast, endlessly proliferating universe in the very first canto. But it is Mab who in this instance has command over Time.

The joy that comes to Ianthe in response to Mab's command is interestingly allied to an alteration in the earth itself, the focus of the succeeding vision. The idea is that earth ('no longer hell' [VIII. 14]) now achieves 'the manhood of its prime' (16), imparted to it by the ripeness of 'Love, freedom, health' (15). One is struck by the deliberate emphasis on maturation, rather than absolute perfection - on the earth revealing in time its own innate potential, a process later identified with the notion of perfectibility. Mythically conceived as a gradually renovated haven even to the point of correcting deficiencies in its original physical geography-the earth becomes intensely habitable and health-giving, as 'man' establishes his proper relationship with it. This symbiosis or synergy indicates that humanity and the earth together constitute a system of mutual self-improvement. The illustrative example of such harmony, forming the climax of Canto VIII, identifies the premise upon which the new order is based, one which, still in the twenty-first century, remains a 'far goal of Time' (to quote Prometheus Unbound); this being the absolute equality and interconnectedness of all life forms - the implicit subject of the essay on vegetarianism (Note 17), and perhaps of the whole composition. ${ }^{42}$

The example is prefaced in two of the most memorable lines of Queen Mab, to which the note is keyed:

no longer now

He slays the lamb that looks him

in the face.... (211-12) 43

What distinguishes the prophetic moment (and this is strikingly original) is the importance given to face-to-face encounter, as if that were the one thing that would always prevent

atrocity and outrage. ${ }^{44}$ Later Shelley's philosophy of non-violent resistance is based on a similar point, that no Englishman would dare to shoot down a defenceless compatriot facing him in a mass demonstration. And defencelessness is, of course, just the point. The appeal of the lamb (as of a household pet), is for clemency: it has no answer to and no defence against the knife that slays. Its appeal is made to whatever remains of the 'human' impulse, the recognition of the other life, and its right to be. The lunatic and heartless slaughter of animals is graphically inscribed in subsequent lines and while the writing has a gothic morbidity - as in 'horribly devours his mangled flesh' (213) to describe the gross habit of meat-eating (which, as Note 17 tells us, is shamefully disguised in cooking) - there is a decisive point to be made that, in an inequitable situation without limits (as we find in gothic), limits established by the fact of relationship rather than imposed boundaries, a descent into brutality or barbarism, the inhuman, must result; and that 'misery, death, disease, and crime' (218) are further inevitable consequences (following the law of necessity). The contrast initiated by 'no longer now' is dramatically effective, withdrawing the ritual horror that, represented on a separate line and in the present tense, has seemingly endured for all time, but is now, in the utopian moment, absent or nullified; and there is nothing gothic about the succeeding Blakean picture in which, idyllically, birds play without dread on the hands of little children, whose relationship with the 'winged inhabitants' (219) is one of 'friendly sport' (223). This curiously unsentimental account of mutuality - unsentimental because the event comes about without effort or design - sets the tone for the momentous declaration: man has lost

His terrible prerogative, and stands

An equal amidst equals.... (225-7)

This is clear-cut, negating the gothic element still aptly present in 'terrible prerogative'. The 
loss, that of a vested right effectively to kill at will, biblically sanctioned (the 'prerogative' of man's dominion in Genesis), indicates the unsustainability of that right; and, in an ironic negative reversal playing on Milton's epic, loss - the loss of a vainglorious edict - is an unqualified gain, the restoration of dignity among everything that exists. The recurring 'stands' re-positions the distinctively upright human form in its mild self-assertion, having yet no greater claim to life than anything else. The moment of autonomy and shared existence-just an 'imagination' of what may be-is implicitly drawn back and reintegrated into the vision of unstratified universal participation over which Queen Mab herself presides for the benefit of her protégé.

WhileMab's presentation (and so that of the poet)continues, throughoutCanto IX, to be utopian, it remains premised on Necessity (the 'HAPPY Earth' being the 'glorious prize of blindlyworking will', 1,5) as well as on the withdrawal of the limiting conditions appertaining to Time, and therefore is grounded in reality (is not, that is, an untrammeled dream fantasy). The future emerges out of, and in memory of, the past and that is why Mab continues to keep the latter in mind. The conditions to which I refer are summed upin a brief passage at the beginning of the canto and are encapsulated in the image of 'Time, the conqueror' (23), the first notable instance of this formulation in Shelley's work, anticipated in the overview of the crumbling of past civilizations in Canto II, 109-210. In lines which themselves anticipate Ozymandias, written some five years later, in 1817, Time's commanding and erosive force is demonstrated in its eventual reduction of pyramids to stones (the craftsman's namelost to posterity), or in its quick and effortless annihilation of 'Yon monarch' who 'in his solitary pomp' / Was but the mushroom of a summer day' (IX. 31-2). ${ }^{45}$ Yet Mab has the best of both worlds: if Time, figured now as 'the king of earth' (34), is no respecter of human achievement or dominion, however enduring it may be, it is finally no match for 'the fixed and virtuous will, / The sacred sympathies of soul and sense / That mocked his fury and prepared his fall' (35-7). As Mab puts it later, 'virtue, love, and pleasure' go 'hand in hand' (75) in what might be described as a celebratory dance, at peace with the earth. ${ }^{46}$ It is not as if Time is destroyed: 'death' remains a 'slow necessity' (57), to which, in age, one naturally and fearlessly yields. Mortality has, in any case, been signalled from the outset, in Ianthe's dormant body. But the tables are turned: mockery is finally at Time's expense, and, whichever way one looks at it, Time has lost its imprisoning and frightening authority - its power to dominate - and is even, to an extent, in the service of humanity. ${ }^{47}$ This layered vision which appears to work its way out of a cul-de-sac is further evidence of the complexity of Shelley's youthful conception and a reminder that one should not take anything for granted in Queen Mab. The 'HAPPY Earth' (1) that is here imagined is an emancipated earth, taking advantage of the inevitable decay of factitious codes and institutions that, in their 'falshood', have defeated or strangled progress. Decaying and abandoned palaces, cathedrals and prisons (the last where 'ruddy children' (115) are at play), are the emblems of historic traces, of the collective memory of vain assertion, and survive into the future merely as relics, bereft of authority.

As the reader's attention has been focused on a 'live' synoptic representation of world history and its anticipated future for some seven and a half cantos, it comes almost as a surprise to realize that it has been only a show put on by the fairy queen, a magic or visionary 'spell', for the edification of Ianthe. Time which, as we have seen, appears in several guises in the whole work (and which just shortly before seemed 'fallen'), now intervenes as commanding as ever, as at the end of a play, to 
close the scene in 'stedfast darkness', and 'the past' (139) - all that, on her celestial voyage, Ianthe has been witness to, which incorporates past, present and future, experienced by her in 'real time' as if in a trance - in the words of Mab herself, 'Fades from our charmed sight' (140). Now the present reality outside the framework of the vision, the reality of Ianthe's day-to-day existence, re-asserts itself. Nothing has really materially changed for Ianthe whose soul, in fairy-tale fashion, must return to her sleeping body and to Henry who, in loving attendance at her bedside (waiting 'to catch/ Light, life and rapture from her smile', I, 29-30), yet seems unsuspecting of her night escapade. On awaking, she is conscious both of Henry and the 'bright beaming stars' that connect her to her cosmic voyage and perspective. The soul returns not transformed (as one might have expected) but rather informed, ready to apply what it has experienced and learned (stored in the memory), and (if Ianthe follows 'virtue's' lesson [IX. 147]) to pursue 'The gradual paths of an aspiring change' (148). This concluding emphasis on Time as a slowly impelled forward continuum is strangely consistent with the utopia just displayed which, though revealed to Ianthe all at once, as an instance of foresight, yet repeatedly intimates the gradualism that is necessary for the vision to realize itself. This movement across the spectrum of Time destabilizes the poem, and for many readers may well be perplexing. But the cyclic return to the historical present with which the poem ends - still to a great extent a 'pathless wilderness'(144)calmly recontextualizes the enchanted vision which has intervened, pointing to the value of Mab's art, that of imaginative projection of possibility, of what might be called poetic faith; to the significance of sleep as an avenue for instructive nocturnal adventure; and to the dialectic between ideal and reality, of what is desirable and what is known or remembered, upon which our lives depend. As the poem once more recalls us unequivocally to the present and its insistent past-laden encroachments - to the 'bigot's creed' (186) and 'tyrant's rod' (187) against which the poet's surrogate, Ianthe, is destined to wage 'eternal war' (190) - it appears that, despite the wealth of promise in the lovers' reunion, the constraints of memory and time are less easily overcome than might have seemed possible.

\author{
University of South Africa \\ alanm.weinberg@gmail.com
}

Notes

1. 2nd edn. (New York, 1st American ed.), viii.

2. The notion of immaturity was earlier seemingly reified by the segregation of Queen Mab amongst Shelley's Juvenilia in the Standard OUP Hutchinson edition of Shelley's poetry (1905, rev. 1970), following Forman's influential 1880 edition of the complete works (where it was placed last under Juvenilia in vol. IV). While this habit has thankfully disappeared in more recent editions of Shelley's poetry and prose - notably those by Matthews and Everest (Longman, 1989), Reiman and Fraistat (Norton, 2002 and Johns Hopkins 2004), and Leader and O'Neill (Oxford, 2003) - the received view that the work is derivative and inexperienced (v. Carlos Baker) or overly ambitious, contradictory and essentially a poem for the young (v. Desmond King-Hele) has marred its reputation, bracketing off the work from serious contemplation. See Baker, Shelley's Major Poetry: The Fabric of a Vision (Princeton, NJ, 1948), 21-40; King-Hele, Shelley: His Thought and Work (3rd edn., London, 1984,), 27-47. In his appraisal of the poem's reception, Jack Donovan remarks: 'Academic criticism has continued to assign Queen Mab a notably modest place in the Shelley canon', adding that 'vestiges of the prepossessions which underlie [Carlos Baker's assessment], and which are rooted in the history of the poem's reception, can still be encountered in apologetic and downright dismissive evaluations of Queen Mab'. See 'Epic Experiments, Queen Mab and Laon and Cythna' in The Oxford Handbook of Percy Bysshe Shelley, eds. Michael O’Neill and Anthony Howe (Oxford 2013), 260.

3. See 'Letter to the Examiner', June 22, 1821, Letters of Percy Bysshe Shelley, ed. F.L. Jones (2 vols, Oxford, 1964), ii. $304-5$.

4. For a scholarly overview of Queen Mab, with explanatory notes, see The Complete Poetry of Percy Bysshe Shelley (hereafter $C P P B S$ ), eds. Donald H. Reiman and Neil Fraistat (3 vols to date, Baltimore and London, 2004), ii. 491-670. Textual citations from Queen Mab refer to this edition. 
5. Bearing in mind that, in the first edition (1813), the keying of lines to relevant notes appears only in the notes themselves.

6. See 'Timothy Morton, 'The Notes to Queen Mab and Shelley's Spinozism', The Neglected Shelley, eds. Alan M. Weinberg and Timothy Webb (Farnham, 2015, 77-94).

7. As with the collection of 'Minor Poems' with which it was first linked in a joint project, Queen Mab shows that Shelley was not, at this time, narrowly biased towards Reason, as is often supposed.

8. For a brilliant unravelling of the radical significance of the term, 'philosophical', see David Duff, Romance and Revolution: Shelley and the Politics of a Genre (Cambridge, 1994), 58-62.

9. See Kenneth Neill Cameron, The Young Shelley: Genesis of a Radical (New York, 1950), 239-74 and David Duff, Romance and Revolution, 54-114. Cameron unfolds Shelley's disparate sources, his departures from them and his radical intent, while Duff shows how suitably the genre of Romance registers the revolutionary dynamics of Queen Mab. For Morton, see p. 91 and n. 6 above. See also Donovan's succinct account of the poem's reception, hybridity and ironic treatment of genre ('Epic Experiments', 256-66).

10. Constantin Volney, Les ruines, ou méditation sur les révolutions des empires (1791). A major source for Queen Mab, Volney's 'prospect' is expansive but mainly human-centred; for this reason alone, one would hesitate to call it visionary.

11. In Earl Wasserman's view, 'time' and 'space' became for Shelley illegitimate constructions. See Shelley: A Critical Reading (Baltimore, 1971).

12. For discussion of the fairy-tale framework and logic of the poem, see Christopher R. Miller, 'Happily Ever After? The Necessity of Fairytale in Queen Mab', in The Unfamiliar Shelley, eds. Alan M. Weinberg and Timothy Webb (Farnham, 2009), 69-84.

13. Duff points to several other sources of the figure of Mab. See Romance and Revolution, 58.

14. See, for example, Michael O’Neill, 'Wrecks of a Dissolving Dream: Shelley's Art of Ambivalence in Hellas', in The Neglected Shelley, 239-60.

15. In Note 9 ('Even love is sold') and later in Laon and Cythna (1817) Shelley positions his conceptions in relation to women's rights, via the pioneering work of Mary Wollstonecraft (A Vindication of the Rights of Woman (1792)) and his acquaintance, James Henry Lawrence (The Empire of the Nairs; or, The Rights of Women.

An Utopian Romance, in Twelve Books (1811))

16. A short story (1752) in which a visitor from a planet circling Sirius visits the earth.

17. Authors who, in Darwin's memorable phrase, had enlisted 'Imagination under the banner of Science': see Advertisement to The Botanic Garden.

18. Spinoza's influence on Shelley is being increasingly noted. See, for example, Christopher Norris, Spinoza \& the Origins of Modern Critical Theory, The Bucknell Lectures in Literary Theory (Oxford, 1991), 300 n. 22; Timothy Morton, 'The Notes to Queen Mab and Shelley's Spinozism', esp. 81-94.

19. See The American Association of Amateur Astronomers, available at http://www.astromax.org/con-page/con88.htm (accessed 9April, 2012).

20. The 'celestial concave' (L. concavus =hollow), as it is called in navigation, refers to the 'spherical dome above us' which 'exists in appearance only': the 'different heavenly bodies ... interspersed in space ... appear ... to be placed or projected on the interior surface of a hollow sphere of infinite magnitude'. J. B. Harbord, Glossary of Navigation: A Vade Mecum for Practical Navigators (1862) (4 ${ }^{\text {th }}$ edn., Glasgow, 1938 rpt. 1965), 58. Shelley's term has Miltonic echoes. See Paradise Lost I. 542 and II. 635.

21. Rightly distinguishing the different mediating voices in Queen Mab, Jessica Smith further claims that the narrator's perspective is partial and rather exclusive in focus. In my view, the narrator positions Mab's (and Ahasuerus's) historicized and prophetic account in Cantos II to IX within the broader narrative framework of fairy-tale romance, and within the cosmic space Mab naturally inhabits. His perspective is therefore not indifferent to history or the future, but inclusive of it. Mab may be said to inhabit his story. See 'Tyrannical Monuments and Discursive Ruins: The Dialogic Landscape of Shelley's Queen Mab', Keats-Shelley Journal, 47 (1998), 108-41.

22. Following Erasmus Darwin's example in The Temple of Nature (1803), Shelley has deliberately dismantled scriptural usage, alluding rather to science as the ground of reverence for the workings of Nature. Interestingly Darwin's subtitle is 'A Poem. With Philosophical Notes'.

23. For Shelley's use of negatives see Timothy Webb, 'The Unascended Heaven: Negatives in Prometheus Unbound' in Shelley Revalued, ed. Kelvin Everest (Leicester, 1983), 37-62.

24. In Shelley's time the universe was still heliocentric, as proposed by Copernicus, Kepler, Galileo and Herschel. Shelley's decentred model seems imaginatively to anticipate more recent discoveries.

25. Probably drawn from Sir William Jones's nine 'Hymns' to Hindu deities (1784-9) and Thomas Maurice's History of Hindostan (1795-8). Jones privileged the Vedantic tradition of non-dualism in his Hymns. See Kurt Andrew Johnson, Sir William Jones and Representations of Hinduism in British Poetry, 1784-1812, PhD thesis, University of York (September, 2010), 219; available at http://etheses.whiterose.ac.uk/1236/ 1/Final_Thesis.pdf.

26. In which 'Time asserts his empire over the ruins', Analysis (2nd edn 1812).

27. 'Mab employs [rhetorical] gestures in order to critique them; her audience therefore must acknowledge the double existence of these gestures as both tyrannical and critical weapons' (Smith, 120). One notes that, having adopted this 
method, Shelley is obliged to use rhetoric himself. His style is polemical and not dispassionate.

28. 'In Queen Mab, Shelley makes great play with Necessity, a concept which has now lost its urgency and is frequently written off as a mere quillet in terminology' (King-Hele, 39). Mistakenly, King-Hele believes that Shelley discarded Necessity as 'a barren concept' after finishing Queen Mab. Nothing could be further from the truth. See, for example, Stuart M. Sperry, 'Necessity and the Role of the Hero in Shelley's Prometheus Unbound', PMLA, 96.2 (March, 1981), 242-54.

29. In note 15 , Shelley implies that hell (like the whole story of Christianity) was an imposture, designed to intimidate sceptics and thus protect those whose earnings ('emoluments', 1l. 21-2) depended on dogmatic adherence to a popular belief.

30. What is given as prophetic certainty in the verse, anticipating the future vision to come, is presented as probability in the Notes (15, CPPBS, ii. 287,

ll. 78-87), in keeping with a more rational perspective. These views are complementary, not contradictory. This is a sophisticated position, suggesting that we can live with both views. It would appear that the vision is not meant to be taken literally.

31. The taboos are still prevalent, as critics tend to sidestep Shelley's atheism, instead of exploring its rationale. Whether Shelley really is an atheist at any stage of his career is difficult to maintain. For some useful reflections, see Gavin Hopps, 'Religion and Ethics: The Necessity of Atheism, A Refutation of Deism, On Christianity', The Oxford Handbook of Percy Bysshe Shelley, 117-31.

32. Similarly Shelley informed Southey that 'God is another signification for the Universe', 2 January 1812, Letters, i. 215.

33. The common estimate following the Masoretic text and famously proposed by Bishop Usher who established the first day of creation as Sunday 23 October 4004 BC.

34. A figure who keeps reappearing in Shelley's work, having appeared as the eponymous protagonist of an earlier verse romance (1810).

35. Another instance of the layered and dialogic nature of Queen Mab.

36. This 'self-enshrined' figure, 'Struggling with whirlwinds of mad agony' (VII, 255) provides the blueprint for the contestation of oppressor and oppressed in Prometheus Unbound.

37. For reflections on Jewish ties with both Ahasuerus and Spinoza, see Nora Crook, 'Shelley, Jews and the Land of Promise' in The Neglected Shelley, 261-79.

38. For further discussion see: Alan Weinberg, “'All Things are sold": The Degrading Intrusiveness of Commerce, with Reference to Shelley's Queen Mab V', Keats-Shelley Review, 20.1 (2006), 102-18. David Duff gives a multisided view of the conception of Virtue in Queen Mab, showing how it departs from the conventional Spenserian model. See Duff, 93-104.

39. A phrase used also at the conclusion of Canto V (257), to suggest that dire events in consequence of selfishness will become just a memory. The idea is now taken a step further.

40. The wonders being 'Space, matter, time, and mind' (VIII. 50), in Spinozan thought, the interwoven attributes of the ultimate reality, God.

41. Poems of Shelley, eds. Geoffrey Matthews and Kelvin Everest (4 vols to date, London, 1989), i. 342.

42. For Shelley everything material is active, therefore 'alive'. See IV. 139-46.

43. Timothy Morton, whose work on Shelley's ecology is invaluable, has repeatedly highlighted these important lines. See for example, 'Shelley's Green Desert', Studies in Romanticism, 35. 3, Green Romanticism Issue (Fall, 1996), 409-10.

44. Cf. Emmanuel Levinas: 'the face is what forbids us to kill', Ethics and Infinity: Conversations with Philippe Nemo, trans. Richard A. Cohen (Pittsburgh, 1985), 86.

45. A very similar passage in prose (possibly meant to be read as verse) was addressed to 'Erin' in a letter to Elizabeth Hitchener, 14 February 1812, Letters, i. 251-2.

46. Noting Shelley's reclaiming of the 'bower of bliss' motif in Spenser's Faerie Queene, David Duff indicates that the 'conception of bliss' in Queen Mab, is 'predicated on "the virtuous mind"', as Ianthe has already learnt in Canto II (Duff, 90).

47. Shelley also explores psychological time (relativity) where a 'minute' might be 'eternity', or a short but virtuous life might seem long-lived. See e.g. Note 16. 